\title{
Elaborasi Nilai Pancasila pada Perjanjian Terapeutik dalam Rangka Pembaharuan Hukum Kesehatan
}

\author{
Yovita Arie Mangesti
}

Fakultas Hukum, Universitas 17 Agustus 1945, Surabaya

mangestiyovita@gmail.com

\author{
Azmi Syahputra \\ Universitas Bung Karno, Jakarta \\ azmicenter@yahoo.com
}

DOI : $10.23917 /$ jjr.v9i1.8093

\begin{tabular}{|c|c|}
\hline $\begin{array}{l}\text { Submission } \\
\text { Track: }\end{array}$ & ABSTRACT \\
\hline $\begin{array}{l}\text { Received: } \\
1 \text { Mei } 2019\end{array}$ & $\begin{array}{l}\text { Tujuan: Artikel ini bertujuan untuk mengelaborasi nilai Pancasila secara substansia } \\
\text { dalam wujud Perjanjian terapeutik dengan tujuan memberikan penghormatan } \\
\text { tertinggi pada harkat dan martabat manusia yang bermuara pada keadilan dalam } \\
\text { dunia kesehatan khususnya pelayanan medis }\end{array}$ \\
\hline
\end{tabular}

Final Revision:

15 Juni 2019

Metodologi: Tulisan ini merupakan hasil penelitian hukum normatif dengan pendekatan undang-undang dan pendekatan konseptual. Pendekatan Undang-undang dilakukan terhadap Undang-Undang Nomor 29 Tahun 2004 tentang Praktik

Available online: Kedokteran, Peraturan Menteri Kesehatan Nomor 290 tahun 2008 tentang 30 Juni 2019 Persetujuan Tindakan Kedokteran. Pendekatan Konseptual dilakukan pada pengkajian nilai Pancasila sebagai dasar untuk membangun model perjanjian terapetik dalam rangka pembaharuan hukum kesehatan.

Corresponding

Author:

Yovita Arie

Mangesti

Temuan: Urgensi rekonstruksi yang memuat tentang prasyarat, bentuk formal versi digital, dan sanksi, yang keseluruhan disusun dan ditetapkan dalam bingkai nilai Pancasila, sebagai wujud pembaharuan hukum kesehatan di era digital.

Kegunaan: Perjanjian terapeutik pada era Revolusi Industri 4.0 menggeser metode manual ke arah digital, sehingga perlu adanya pembaharuan hukum untuk meletakan nilai kemanusiaan, permufakatan, dan keadilan, melalui formulasi kontrak yang tepat dan dapat memberikan perlindungan hukum bagi pelaku dan pengguna layanan kesehatan

Kebaruan/Orisinalitas: Keberadaan Tenaga Advokasi medis, merupakan novelty dari Perjanjian terapeutik yang kiranya dapat dikonstruksi sebagai hukum positif, dalam rangka pembaharuan hukum kesehatan.

Keywords: Pancasila, perjanjian terapeutik, hukum kesehatan 


\section{PENDAHULUAN}

Perjanjian terapeutik pada dasarnya mempertegas hubungan hukum antara pemberi dan penerima layanan kesehatan, yang dalam tulisan ini dibatasi dalam hubungan antara dokter dan pasien. Perjanjian terapeutik ini menggunakan kaedah umum hukum perjanjian pada umumnya sebagaimana diatur dalam Buurgerlijk weetboek (kitab undang-undang hukum perdata), dengan mempedomani standar profesi pelayanan medis. Undang-undang Nomor 36 Tahun 2009 tentang Kesehatan menyatakan bahwa para pihak dalam Perjanjian terapeutik adalah pasien dengan tenaga kesehatan, sedangkan dalam Undang-undang Nomor 29 tahun 2004 tentang Praktik Kedokteran menyebutkan bahwa para pihak dalam Perjanjian teurapeutik adalah pasien dan dokter/dokter gigi. Pada tulisan ini, dengan mempertimbangkan keberadaan Peraturan Menteri Kesehatan Nomor 290 tahun 2008 tentang Persetujuan Tindakan Kedokteran, penulis menggunakan terminologi Perjanjian terapeutik sebagai perjanjian antara dokter/dokter gigi dengan pasien untuk melakukan tindakan kedokteran.

Dokter dan Pasien merupakan subyek hukum manusia yang secara ontologis adalah makhluk multidimensional. Manusia sebagai makhluk individu dan makhluk sosial. Dari konteks bahwa manusia adalah makhluk sosial ini maka dalam proses hidup sehari-hari dibutuhkan perjanjian yang mendasari hubungan hukum para pihak untuk mengatur kebutuhan hidup yang berhadap-hadapan dengan hak dan kewajiban.

Hukum perjanjian membingkai hubungan hukum antara dokter dan pasien disusun dengan pondasi nilai Pancasila sebagai rechtsidee hukum Indonesia sekaligus staatfundamental norm. Perjanjian terapeutik adalah perjanjian antara pasien dan dokter dalam pelayanan medis profesional. Pelayanan medis profesional ini meliputi diagnostik, prefentif, rehabilitatif dan promotif.

Tulisan ini mengkaji bagaimana nilai Pancasila terelaborasi secara substansial dalam wujud Perjanjian terapeutik dengan tujuan memberikan penghormatan tertinggi pada harkat dan martabat manusia yang bermuara pada keadilan dalam dunia kesehatan khususnya pelayanan medis. Pancasila ditempatkan sebangkai bingkai praksis moral, yaitu usaha yang terus menerus berbasis determinasi moral untuk hidup terhormat, tidak merugikan orang, jujur, bertanggungjawab untuk mewujudkan kebaikan bagi manusia secara nyata. 


\section{METODOLOGI PENELITIAN}

Tulisan ini merupakan hasil penelitian hukum normatif dengan pendekatan undangundang (statute approach) dan pendekatan konseptual (conceptual approach). Pendekatan Undang-undang dilakukan terhadap Undang-Undang Nomor 29 Tahun 2004 tentang Praktik Kedokteran, Peraturan Menteri Kesehatan Nomor 290 tahun 2008 tentang Persetujuan Tindakan Kedokteran. Pendekatan Konseptual dilakukan pada pengkajian nilai Pancasila sebagai dasar untuk membangun model perjanjian terapetik dalam rangka pembaharuan hukum kesehatan.

\section{PEMBAHASAN}

Perjanjian Terapeutik, yaitu sebagai: Kontrak yang dibuat antara pasien dengan tenaga kesehatan dan/atau dokter atau dokter gigi, di mana tenaga kesehatan dan/atau dokter atau dokter gigi berusaha melakukan upaya maksimal untuk melakukan penyembuhan terhadap pasien sesuai dengan kesepakatan yang dibuat antara keduanya dan pasien berkewajiban membayar biaya penyembuhannya. Hubungan dokter dan pasien dalam perjanjian terapeutik (perjanjian medis) bertumpu pada dua macam hak asasi yang merupakan hak dasar manusia, yaitu : Hak untuk menentukan nasib sendiri (the right to self-determinations), serta Hak atas dasar informasi (the right to informations)

Pancasila selain sebagai sumber hukun (source of law) tetapi juga sebagai sumber etika (source of ethics) bersifat terbuka dalam hal mengembangkan hak asas manusia. Kesehatan merupakan hak manusia yang harus terpenuhi. Pada falsafah ini terkandung nilai manusia sebagai makluk yang suci dari awal penciptaannya (sancity of human life).

Fred Ameln yang mengartikan Kontrak atau Perjanjian terapeutik dengan "kontrak dimana pihak dokter berupaya maksimal menyembuhkan pasien (inspaningsverbintenis) jarang merupakan kontrak yang sudah pasti (resultastsverbintenis). Maka, Perjanjian terapeutik memiliki asas yang sama dengan asas dalam perjanjian umum yang dibuat dibawah payung hukum perdata, yaitu: Asas Kebebasan Berkontrak (freedom of contract), Konsensualisme (concensualism), Kepastian Hukum (pacta sunt servanda), Kepastian Hukum (pacta sunt servanda), Asas Itikad Baik (good faith), Asas Kepribadian (personality). 
Perjanjian dalam bentuk yang paling klasik, dipandang sebagai ekspresi kebebasan manusia untuk memilih dan mengadakan perjanjian. Pernajian merupakan wujud dari kebebasan (freedom of contract) dan kehendak bebas untuk memilih (freedom of choice).

Sifat perjanjian secara umum terbagi menjadi dua, yaitu:

a. Inspaning verbintenis, merupakan suatu perjanjian upaya di mana kedua belah pihak sepakat untuk berupaya secara maksimal untuk mewujudkan apa yang diperjanjikan.

b. Resultaat verbintenis, merupakan suatu perjanjian yang memberikan hasil (resultaat) yang nyata sesuai yang diperjanjikan.

Setiap tindakan medis harus dengan persetujuan tertulis yang ditandatangani oleh yang berhak meberikan persetujuan. Persetujuan ini berfungsi untuk sebagai instrument pertanggungjawaban atas tindakan medis.

\section{A. KONSTRUKSI NILAI PANCASILA DALAM ASAS-ASAS PERJANJIAN TERAPEUTIK}

Nilai-nilai Pancasila merupakan kristalisasi dari ontology manusia itu sendiri yang bersifat monodualis. ${ }^{1}$ Manusia utuh jiwa dan raga, yang juga bercirikan makhluk pribadi sekaligus makhluk sosial. Manusia adalah persona, yang sempurna. ${ }^{2}$ Makhluk sosial terbentuk karena adanya interaksi di mana kedua belah pihak saling membutuhkan. Perjanjian terapeutik terjadi dalam hal pasien membutuhkan kesembuhan dan dokter sebagai pihak lain membutuhkan terwujudnya suatu pelayanan professional. Pasien menurut Undangundang Nomor 29 tahun 2004 tentang Praktik Kedokteran pasal 1 angka 10 menyebutkan bahwa pasien adalah setiap orang yang melakukan konsultasi masalah kesehatannya langsung maupun tidak langsung kepada dokter/dokter gigi. Dari definisi ini, dokter berkepentingan menyembuhkan sedangkan kepentingan pasien adalah untuk mendapatkan kesehatan. Ketika kepentingan hukum ini berhadap-hadapan, maka di butuhkan sebuah Perjanjian terapeutik yang memberikan perlindungan hukum kepada kedua belah pihak.

Bekerjanya Perjanjian terapeutik ini sama asas dengan perjanjian pada umumnya. Nilai Pancasila terkonstruksi dalam asas Perjanjian terapeutik, sebagai berikut:

a. Perjanjian terapeutik berasaskan Konsensualisme (concensualism). Pasal 1320 ayat (1) KUH Perdata menegaskan bahwa salah satu syarat sahnya perjanjian ${ }^{3}$ adalah

\footnotetext{
${ }^{1}$ Kaelan, Filsafat Pancasila Pandangan Hidup Bangsa Indonesia, Yogyakarta: Paradigma, 2002, 165-170

${ }^{2}$ Sumaryono, Etika Hukum, Relevansi Hukum Kodrat Thimas Aquinas, Yogyakarta: Kanisius, 2020, 98

${ }^{3}$ Hardijan Rusli ,Hukum Perjanjian Indonesia dan Common Law, Pustaka Sinar Harapan: Jakarta, 1996, 16
} 
adanya kesepakatan antara kedua belah pihak. Peradaban manusia bergulir terus, menghantar manusia pada era peradaban aksara, di mana manusia tidak hanya menggunakan perjanjian lisan, tetapi mampu menulisnya dalam aksara hingga menulis digital di zaman ini. Perjanjian yang semula lisan dan mengikat sebagai undang-undang, diperkuat dalam bentuk perjanjian tertulis yang selanjutnya menjadi hukum bagi kedua belah pihak.

Sila kedua butir ke-9 berbunyi bahwa bangsa Indonesia merasa dirinya bagian dari seluruh bangsa di dunia, dilanjutkan pada butir ke-10 bahwa bangsa Indonesia mengembangkan sikap hormat menghormati dan bekerjasama dengan bangsa lain. Bentuk kerjasama juga tercermin dalam perjanjian terapeutik dimana antara dokter dan pasien tidak mungkin mencapai hasil tanpa adanya kesepakatan yang melandasi bentuk kerjasama tersebut. Perjanjian terapeutik berasaskan Asas Kebebasan Berkontrak (freedom of contract).

Pasal 1338 ayat (1) KUH Perdata, menegaskan bahwa suatu perjanjian yang dibuat secara sah berlaku sebagai undang-undang bagi mereka yang membuatnya. Frasa “mereka yang membuatnya" implisit adalah dua subyek hukum monodualis, yang menjunjung tinggi persamaan derajat, persamaan hak, dan kewajiban asasi setiap manusia, tanpa membeda-bedakan suku, keturunan, agama, kepercayaan, jenis kelamin, kedudukan sosial, warna kulit dan sebagainya. (sila kedua butir ke-2 dan sila keempat butir ke-1). Asas ini merupakan asas kebebasan, yang dalam Butirbutir Pancasila dimaknai sebagai tidak boleh memaksakan kehendak kepada orang lain (Sila keempat butir ke-2).

Pasal 1338 KUH Perdata, frasa "berlaku sebagai undang-undang” menunjukkan bahwa dengan kebebasannya manusia membuat kontrak hak dan kewajiban yang bersifat resiprositas dan harus dipenuhi oleh kedua belah pihak secara adil. Keadilan dalam sila ke-5 Pancasila dimaknai sebagai menjaga keseimbangan antara hak dan kewajiban. (sila kelima butir ke-3).

b. Asas Kepastian Hukum (pacta sunt servanda) merupakan asas yang berhubungan dengan akibat perjanjian. Asas pacta sunt servanda merupakan asas bahwa substansi perjanjian terapetik jarus ditaati oleh pihak yang membuat (oleh dokter dan pasien) dan para pihak yang terkait. Tidak boleh melakukan intervensi terhadap 
substansi kontrak yang dibuat oleh para pihak. Asas pacta sunt servanda sebagaimana diatur dalam Pasal 1338 ayat (1) KUH Perdata selaras dengan sila kelima yakni dalam penjabaran butir ke-3 dan ke-4, yang masing-masing berbunyi menjaga keseimbangan hak dan kewajiban, menghormati hak orang lain.

c. Asas Itikad Baik (good faith) dalam Pasal 1338 ayat (3) KUH Perdata yang berbunyi: "Perjanjian harus dilaksanakan dengan itikad baik." Pada perjanjian terapeutik, asas ini terlaksana atas dasar kepercayaan atau keyakinan yang teguh maupun kemauan baik dari para pihak. Asas itikad baik terbagi menjadi dua macam, yakni itikad baik nisbi dan itikad baik mutlak. Pada itikad yang pertama, seseorang memperhatikan sikap dan tingkah laku yang nyata dari subjek. Pada itikad yang kedua, penilaian terletak pada akal sehat dan keadilan serta dibuat ukuran yang obyektif untuk menilai keadaan (penilaian tidak memihak) menurut norma-norma yang objektif. Nilai Pancasila dalam asas ini dijabarkan pada sila keempat butir ke-6yaitu iktikad baik dan rasa tanggung jawab menerima dan melaksanakan perjanjian terapeutik tersebut dengan mengindahkan proses sebelumnya yaitu musyawarah antar dokter dan pasien yang dilakukan dengan akal sehat dan sesuai dengan hati nurani yang luhur. Terapi yang diambil harus dapat dipertanggungjawabkan secara moral kepada Tuhan Yang Maha Esa, menjunjung tinggi harkat dan martabat manusia, nilai-nilai kebenaran dan keadilan mengutamakan persatuan dan kesatuan demi kepentingan bersama.

d. Asas Kepribadian (personality) asas yang menentukan bahwa seseorang yang akan melakukan dan/atau membuat Perjanjian terapeutik hanya untuk kepentingan perseorangan saja. Pasal 1315 dan Pasal 1340 KUH Perdata. Pasal 1315 KUH Perdata menegaskan: "Pada umumnya seseorang tidak dapat mengadakan perikatan atau perjanjian selain untuk dirinya sendiri." Inti ketentuan ini sudah jelas bahwa untuk mengadakan suatu perjanjian, orang tersebut harus untuk kepentingan dirinya sendiri. Pasal 1340 KUHPerdata berbunyi: "Perjanjian hanya berlaku antara pihak yang membuatnya." Hal ini mengandung maksud bahwa perjanjian yang dibuat oleh para pihak hanya berlaku bagi mereka yang membuatnya. Namun demikian, ketentuan itu terdapat pengecualiannya sebagaimana diintrodusir dalam Pasal 1317 KUH Perdata yang menyatakan: "Dapat pula perjanjian diadakan untuk 
kepentingan pihak ketiga, bila suatu perjanjian yang dibuat untuk diri sendiri, atau suatu pemberian kepada orang lain, mengandung suatu syarat semacam itu."

Asas personality ini merupakan sentral terpadunya nilai Pancasila dalam perjanjian terapeutik. Dimulai dari pemahaman bahwa manusia adalah makhluk monodualis, yang memiliki harkat dan martabat sejak ada-nya sebagai manusia yang mengejawantahkan eksistensi dirinya sebagai makhluk sosial, yang harus merperilaku adil terhadap sesamanya.

Asas ini memberikan penghargaan hakiki terhadap Perjanjian terapeutik yang hanya bertujuan semata-mata untuk kepentingan pelayanan medis yang menjujung tinggi nilai intrinsik maupun ekstrinsik manusia itu sendiri.

Kajian terhadap asas-asas yang bekerja dalam perjanjian terapeutik ini menunjukkan bahwa dalam hubungan hukum privat dokter dan pasien dilindungi dengan bingkai nilai Pancasila, sehingga Perjanjian terapeutik tersebut keberadaannya harus dilepaskan dari segala bentuk exploitasi, dehumanisasi, atau mengancam hak manusiawi. Kelemahan yang sering terjadi bahwa antara dokter/dokter gigi dan pasien telah terjadi beberapa kesenjangan (gap), yaitu:

a. kesenjangan pengetahuan di bidang kedokteran. Pasien biasanya tidak paham pengetahuan medis, sehingga ketika membuat persetujuan dibutuhkan adanya keterangan yang benar, baik dan lengkap kepada pasien mulai dari tahap anamnesis, diaknosis ataupun sebelum melakukan tindakan kedokteran. Pasien tidak mengajukan tuntutan atas adanya malpraktik, maladministrasi, pelanggaran kode etik, justru karena pasien tidak paham bahwa dia sedang mengalami hal tersebut. Rasa pasrah dan percaya pada kemampuan dokter bisa jadi mempermudah disetujuinya suatu Perjajian terapeutik, tetapi di sisi yang lain terjadi ketimbangan hak.

b. kesenjangan antara bahasa medis dan Bahasa sehari-hari. Istilah, terminologi, dan analogi dalam dunia medis seringkali sulit untuk dicari terjemahannya untuk dapat dikatakan secara langsung dengan bahasa sehari-hari, sehingga sulit untuk dipahami masyarakat. Banyak istilah medis yang sulit dicari padanannya pada Bahasa sehari-hari. Hal ini yang mengakibatkan bahwa pasien dalam keadaan sakit menjadi subyek hukum yang penurut, yang dengan mudah atau spontan 
langsung menandatangi form informed consent yang juga sebenarnya tidak ia mengerti.

c. kesenjangan sosial. Dokter/ dokter gigi dianggap lebih tinggi status sosialnya dibandingkan pasien. Hal ini yang sering tanpa disadari sebagai sekat informasi antara dokter dan pasien. Pasien untuk bertanya terus tidak berani / malu, sedangkan dokter menganggap persetujuan sudah diberikan tanpa cela.

Atas kesenjangan tersebut maka Perjanjian Terapeutik berpotensi untuk berat sebelah (tidak adil), kesepakatan yang dibangun hanya atas kepercayaan, bukan atas kesepahaman. Kesepakatan yang dibangun atas kepercayaan tentunya tidak memiliki indikaor yang jelas, kepercayaan bisa memusar ketika pasien tak kunjung sembuh bahkan membalas untuk menyerang dokter/dokter gigi sebagai wan prestasi. Sedangkan kesepakatan yang dibangun atas dasar pemahaman nantinya dapat menjadi standar evaluasi (progress indicator) pada setiap tahapan-tahapan tindakan kedokteran yang dikerjakan oleh dokter.

\section{B. MODEL PERJANJIAN TERAPEUTIK BERDASAR NILAI PANCASILA}

Perenungan mendasar yang harus dijawab adalah: "kapan sesungguhnya Perjanjian Terapeutik tersebut dimulai, kapan nilai-nilai Pancasila sebagai visi bertindak para pihak dalam perjanjian terapeutik ini mulai menjadi payung pelindungan hukum (legal protection)”. Undang-undang Nomor 29 tahun 2004 tentang Praktik Kedokteran, pada pasal 45, tentang Persetujuan Tindakan Kedokteran atau Kedokteran gigi, berbunyi sebagai berikut:

(1) Setiap tindakan kedokteran atau kedokteran gigi yang akan dilakukan oleh dokter atau dokter gigi terhadap pasien harus mendapat persetujuan.

(2) Persetujuan sebagaimana dimaksud pada ayat (1) diberikan setelah pasien mendapat penjelasan secara lengkap.

(3) Penjelasan sebagaimana dimaksud pada ayat (2) sekurang-kurangnya mencakup:

a. diagnosis dan tata cara tindakan medis;

b. tujuan tindakan medis yang dilakukan;

c. alternatif tindakan lain dan risikonya;

d. risiko dan komplikasi yang mungkin terjadi; dan

e. prognosis terhadap tindakan yang dilakukan.

(4) Persetujuan sebagaimana dimaksud pada ayat (2) dapat diberikan baik secara tertulis maupun lisan.

(5) Setiap tindakan kedokteran atau kedokteran gigin yang mengandung resiko tinggi harus diberikan dengan persetujuan tertilis yang ditandatangani oleh yang berhak memberikan persetujuan 
(6) Ketentuan mengenai tata cara persetujuan tindakan kedokteran atau kedokteran gigi sebagaimana dimaksud pada ayat (1), ayat (2), ayat (3), ayat (4), dan ayat (5) diatur dengan Peraturan Menteri.

Regulasi ini dilihat dari perspektif nilai Pancasila, dimaknai sebagai berikut:

a. Perjanjian terapeutik dimulai pada saat Pasien sudah mendapatkan penjelasan. Pada tahap ini, tampak bahwa persetujuan tidak tercapai tanpa mufakat, untuk mencapai keseimbangan atau keadilan.

b. Sebelum persetujuan ada Proses yang tidak bisa ditinggalkan,. Sebutlah ini sebagai proses Pra-persetujuan, yaitu proses dimana pasien mendapatkan penjelasan atau informasi apapun terkait penyakitnya. Informasi tidak hanya menyangkut tindakan medis, tetapi termasuk berapa biaya yang harus dikeluarkan pasien. Hal ini merupakan upaya mewujutkan nilai keadilan. Di satu pihak dokter/dokter gigi menerima imbal jasa karena profesi dan keahliannya, di sisi lainnya pasien mendapatkan kesembuhan.

c. Pemberian persetujuan tidak boleh mencederai hakikat kemanusiaan pasien. Rasa kemanusiaan pasien terpenuhi jika dalam proses ini pasien dipandang sebagai subyek, bukan obyek. Jika pasien dimaknai sebagai obyek berarti dia diperlakukan sebagai alat, sedangkan pada tindakan kedokteran, pasien adalah subyek dengan kepenuhan jati dirinya yang diberi hak konstitusional oleh undang-undang itu sendiri.

Point pentingnya adalah bahwa Pelayanan kedokteran meliputi dua proses yang tak bisa dipisahkan, yaitu proses Pra-persetujuan dan Pemberian Persetujuan. Dokter hanya melakukan tindakan setelah adanya Persetujuan Tindakan Kedokteran. Di negara yang Pancasilais, berlaku nilai kemanusiaan, musyawarah-mufakat, dan keadilan sosial. Implementasi ketiga nilai ini adalah pada proses Pra-persetujuan, dimana informasi harus diberikan secara benar, baik, dan lengkap.

Kecacatan informasi pada tahap pra-persetujuan itu sama artinya dengan pembohongan publik. Hal ini akan menyebabkan exploitasi dan dehumanisasi. Misalnya: pasien dipaksa untuk melakukan serangkaian pemeriksaan Laboratorium darah, EKG, USG, rontgen, CT Scan, MRI, Ecocardiography, Treatmill test, dan sebagainya, yang mungkin tidak 
perlu. Hanya dokter yang mengetahui hidden reasons dari serangkaian pemeriksaan ini. Tindakan-tindakan yang berwujud supply reduce demand, tidak dibenarkan dalam praktik kedokteran.

Perjanjian terapeutik merupakan hukum dalam praktik kedokteran. Pada perkembangannya, sekularisasi ${ }^{4}$ sedemikian berpengaruh pada hukum, termasuk hukum dan positivisasi nilai ${ }^{5}$ yang memayungi Perjanjian Terapeutik. Sekularisasi seringkali memisahkan hukum dari basis nilainya, yaitu nilai ketuhanan (transendensi), sehingga hukum modern, termasuk Perjanjian terapeutik lebih bersifat materialistik, hedonistik, bahkan atheistik, yang akhirnya menggerus nilai kemanusiaan itu sendiri. Pada konteks hukum kesehatan Indonesia, nilai Pancasila berkedudukan sebagai rechtsidee bahkan staatfundamental norm dari segala hukum positif. Hal ini tidak luput dari keberadaan Perjanjian Terapeutik sebagai satu-satunya perikatan dan setiap perikatan memiliki kekuatan hukum.

Perjanjian terapeutik yang Pancasilais akan terwujud jika tercapai nilai perlindungan dan keselamatan pasien. Perjanjian terapeutik berfungsi sebagai instrumen etika dan hukum. Sifat perjanjian adalah inspaning verbintenis, yang hanya berupa perjanjian upaya. Tidak ada hal konkrit sebagai hasil yang bisa diprediksi. Seorang pasien yang berobat ke dokter tidak bisa dijanji akan akan sembuh. Setiap teapi yang diberikan selalu berpotensi adanya efek samping pengobatan dan atau risiko medis. Praktik kedokteran, dimulai dengan kepercayaan dan diakhiri dengan hasil yang bersifat unpredictable. Maka dibutuhkan itikad baik dari kedua belah pihak. Itikad baik yang diwujudkan dengan tindakan koperatif, kerjasama dari pasien. Keterlibatan pasien secara penuh dalam mewujudkan perjanjian ini berpengaruh besar dalam pencapaian hasil.

Selanjutnya dalam Peraturan Menteri Kesehatan Nomor 290 Tahun 2008 tentang Persetujuan Tindakan Kedokteran, bahwa Persetujuan tindakan kedokteran adalah persetujuan yang diberikan oleh pasien atau keluarga terdekat setelah mendapat penjelasan secara lengkap mengenai tindakan kedokteran atau kedokteran gigi yang akan dilakukan terhadappasien. Kajian terhadap substansi dan struktur regulasi ini menunjukkan nilai kemanusiaan, musyawarah-mufakat, dan keadilan sosial seharusnya menjadi pilar-pilar penyangga, yang menentukan apakah Perjanjian Terapeutik sungguh mampu menjadi bangunan perlindungan hukum bagi kedua belah pihak.

\footnotetext{
${ }^{4}$ Yovita A. Mangesti, Hukum Berparadigma Kemanusiaan, Yogyakarta, Genta Publishing, 2016, 70-71

${ }^{5}$ Syamsudin, Ilmu Hukum Profetik, Gagasan Awal Landasan Kefilsafatan dan Kemungkinan Perkembangannya di Era Postmodern, Yogyakarta: PSH-UI, 2013,198
} 
Untuk mewujudkan nilai-nilai Pancasila itu menjadi pondasi dalam Perjanjian Terapeutik, maka penulis menyarankan beberapa standar yang harus ada pada Perjanjian Terapeutik:

a. Tindakan Kedokteran dijelaskan dengan benar, baik, dan lengkap.

b. Pasien dapat didampingi oleh keluarganya atau tenaga advokasi medis.

c. Tidak melakukan provokasi dan intimidasi dengan menggunakan dalil keilmuan.

d. Risiko, rasa nyeri, dan ketidaknyaman (discomfort) dari tindakan dan pengobatan yang mungkin dialami pasien, harus dijelaskan secara terbuka.

e. Persetujuan hanya diberikan oleh pasien, setelah pasien sungguh memahami semua fakta kesehatan dan penyakit yang dideritanya.

f. Pasien menandatangani form persetujuan (pernyataan Persetujuan tindakan Kedokteran) hanya untuk satu jenis tindakan.

g. Persetujuan Tindakan Kedokteran selalu diperbaharui terkait dengan perubahan apapun atas tindakan yang diberikan, semata-mata untuk kepentingan pasien.

h. Pasien berhak untuk melihat data pengobatan dirinya.

Perihal Tenaga Advokasi medis memang belum ada tercantum dalam perundangundangan. Tenaga Advokasi medis ini dapat terdiri dari tenaga kesehatan atau profesional lain (psikolog, ahli bahasa lisan maupun isyarat, konsultan hukum) yang dianggap dapat mendampingi pasien untuk sungguh-sungguh memahami penjelasan dari dokter/dokter gigi terhadap tindakan kedokteran. Sebuah perjanjian tidak memiliki daya sebagai instrumen hukum karena proses komunikasi gagal mengakomodir kepantingan yang diametral.Perjanjian terapeutik pun sangat mungkin sama ketika penjelasan tidak dipahami, atau bahkan dipolitisir untuk keuntungan masing-masing. Sekali lagi, bahwa perjanjian ini bersifat inspaning verbinteis, kesepakatan dibuat dalam keadaan unpredictabel result, pada usaha kesembuhkan, dan dibutuhkan kesadaran tinggi dari pasien untuk merupaya menyembuhkan dirinya juga. Pasien tidak bisa mnuntut dokter/dokter gigi segamblang pada perjanjian yang bersifat resultaat verbintenis. Kehadiran seorang Tenaga Advokasi Medis akan sangat membantu pasien dalam menemukan keadilan ketika terjadi hal-hal terkait adanya kesalahan tindakan kedokteran, adanya risiko medis, atau hal lain yang berhubungan dengan percepatan penyembuhan pasien. 
Fungsi Tenaga Advokasi medis ini adalah untuk membantu pasien dan keluarga, melakukan fungsi check and balances sehingga nilai kemanusiaan, musyawarah-mufakat, dan keadilan sosial dapat tercapai. Sebuah proses sosial membutuhkan kontrol dari masyarakat, demikian juga dalam praktik kedokteran. Ketidaktahuan pasien ini menjadikan pasien sebagai vulnerable person yang rawan untuk terjadinya instrumentalisasi terhadap pasien. Instrumentalisasi berarti menjadikan pasien sebagai alat. Bisa jadi sebagai alat uji coba terapi, subyek penelitian, bahkan alat ekonomi karena di masa sekarang, pelayanan kedokteranpun memiliki nilai komoditi.

Keberadaan Tenaga Advokasi medis ini membutuhkan regulasi lebih lanjut, sebagai suatu terobosan baru yang mengawal hubungan dokter-pasien sampai Perjanjian terapeutik berakhir, yaitu pada saat pasien menyatakan dirinya sudah sembuh. Tenaga Advokasi medis dalam fungsi pendampingannya disesuaikan dengan kepentingan pasien.

Perkembangan layanan hingga industri kesehatan pada era digital berupa praktik telemedicine dengan media internet. Telemedice ini sangat membutuhkan jasa Tim Advokasi medis, karena praktik kedokteran pada telemedicine berbeda dengan pengobatan konvensional. Pasien harus terlibat secara aktif dalam mendiskripsikan keluhan yang dideritanya. Telemedicine masih tergolong inkonvensional karena Perjanjian terapeutik pada tahap kesepakatan, dilakukan tanpa anamnesis dan diagnosis yang lengkap. Tidak ada sentuhan fisik, demikian pula tanda tangan persetujuan tidak selalu dalam bentuk tanda tangan digital, hanya pernyataan perangkat digital saja.

Perlu regulasi yang melindungi Perjanjian terapeutik telemedicine. Dokter/dokter gigi seharusnya tetap dilindungi undang-undang, demikian pula pasien. Pasien seringkali malas datang karena selain kondisi fisik dari tubuh membuat malas untuk bergerak, atau bisa jadi jarak tempuh ke unit layanan kesehatan juga jauh. Di sisi lain pasien sering beranggapan bahwa dokter/dokter gigi yang memeriksa tanpa melihat atau menyentuh langsung adalah dokter /dokter gifi yang hebat. Padahal justru dengan demikian pasien dikurangi dalam hak konstitusionalnya. Antisipasi terhadap konflik yang muncul, maka perlu adanya bantuan Tenaga Advokasi medis, sehingga para pihak dapat terlayani sesuai hak dan kewajibannya.

Perjanjian Terapeutik sama dengan Perjanjian lainnya yang berasaskan resiprositas atau adanya hubungan timbal balik pelaksanaan hak dan kewajiban. Hak dan kewajiban dokter dan pasien berhadap-hadapan. Hak pasien merupakan kewajiban yang harus diilakukan dokter/dokter gigu. Hak dokter/dokter gigi merupakan kewajiban pasien. 
Kewajiban harus dipandang sebagai prima facie. ${ }^{6}$ Kesinambungan hak dan kewajiban ini menghasilkan adanya perlindungan hukum, yang otomatis didapatkan dalam model Perjanjian Terapeutik ini. Tanggung jawab atas terpenuhi hak itu merupakan prestasi sedangkan pengingkaran kewajiban dapat menjadikan wan prestasi.

Indikator telah terjadi wanprestasi atau tidak adalah seluruh isi dari Pra-persetujuan dapat tercapai. Tindakan Kedokteran yang sejak Pra-persetujuan itu dijelaskan dengan benar, baik, dan lengkap akan memberikan perlindungan bagi dokter untuk lepas dari somasi dan gugatan pasien atas alasan ketidaktahuan. Penjelasan yang lengkap merupakan perwujudan adanya penghargaan terhadap pasien sebagai insan yang bermartabat.

Pendampingan keluarga atau tenaga advokasi medis, sekaligus sebagai saksi atas adanya kemungkinan dokter menjadi tertuduh melakukan perbuatan inkonstitusional yang melanggar etika dan hukum praktik kedokteran.

Etika dan hukum praktik kedokteran tidak mengizinkan untuk adanya provokasi dan intimidasi dengan menggunakan dalil keilmuan. Superioritas profesional baik dari dokter terhadap pasien, atau dari intitusi bagi pasien, tidak boleh dijadikan alasan pembenar atas semua tindakan kedokteran. Sering terjadi, dokter diprovokasi untuk menggunakan obatobatan tertentu atau jenis pemeriksaan tertentu demi perjanjian bisnis lainnya dengan pihak farmasi dan institusi. Untuk dapat mengoptimalkan tindakan kedokteran haruslah, dokter dan pasien harus sama-sama merasa rasa aman dan nyaman. Dokter/ dokter gigi semestinya otonom, sehingga kemungkinan fraud dalam pelayanan kedokteran dapat diminimalisir.

Perjanjian Terapeutik membutuhkan serangkaian Penjelasan atas adanya Risiko, rasa nyeri, dan ketidaknyaman (discomfort) dari tindakan dan pengobatan yang mungkin dialami pasien,sekaligus merupakan antisipasi terhadap keadaan risiko di luar dari kemampuan dokter sebagai profesional medis.

Bagaimanapun juga, dampak positivisme hukum mengharuskan bahwa hukum memiliki perangkat alat bukti tertulis. Satu-satunya instrumen hukum dalam praktik kedokteran adalah Perjanjian terapeutik. Perjanjian terapeutik bentuknya analog dengan dokumen hukum. Maka Persetujuan yang diberikan oleh pasien, setelah pasien sungguh memahami semua fakta kesehatan dan penyakit yang dideritanya, merupakan alat bukti atas adanya dugaan malpraktik maupun maladministrasi.

\footnotetext{
${ }^{6}$ Khudzaifah Dimyati, Pemikiran Hukum, Konstruksi Epistemologis Berbasis Budaya Hukum Indonesia, 2014, 27
} 
Sebagaimana perjanjian pada umumnya, bahwa perjanjian hanya dibuat untuk suatu hal tertentu (obyek tertentu), maka dengan pasien menandatangani form persetujuan (pernyataan Persetujuan tindakan Kedokteran) hanya untuk satu jenis tindakan, dokter/dokter gigi hanya memiliki tanggungjawab hukum terhadap satu tindakan tersebut, dan tidak dapat ditafsirkan dengan perluasan makna. Hal ini berlaku pula untuk perubahan tindakan, ataupun penambahan tindakan.

Perjanjian terapeutik sebagai dokumen hukum, hak milik atas Perjanjian ini melekat pada pasien. Maka pasien berhak untuk melihat data pengobatan dirinya yang telah terdokumentasi. Pada dokumen ini pun akan tampak keseluruhan peristiwa hukum yang telah dilaksanakan sebagai wujud "prestasi” bagi kedua belah pihak.

Keseluruhan proses dan hasil yang tertera pada Perjanjian terapeutik, baik dalam tahap Pra-persetujuan hingga Persetujuan, seorang dokter berada pada posisi superior dibanding pasien. Superioritas ini akibat adanya "proffesional power". Jika kondisi ini dibiarkan tanpa keseimbangan tentu akan berpengaruh pada kondisi fisik maupun psikis. Sedangkan ajaran Pancasila memandang manusia sebagai makhluk monodualis (fisik dan psikis) yang harus terus menerus diperjuangkan untuk semakin berkualitas di berbagai sisi kehidupan. Kedelapan standar Perjanjian terapeutik tersebut di atas, merupakan implementasi nilai Pancasila, yang berfungsi sebagai legal protection, karenanya mutlak harus ada dalam setiap tindakan kedokteran

\section{PENUTUP}

Perjanjian terapeutik merupakan dasar hukum bagi hubungan hukum dokter pasien. Perjanjian terapeutik ini sah apabila kedua belah pihak mencapai kata sepakat yang diwujudkan melalui Persetujuan Tindakan Kedokteran (Informed Consent). Model Perjanjian terapetik berbasis pada nilai Pancasila tercermin melalui 8 (delapan) standar yang penulis tawarkan, yaitu: Tindakan Kedokteran dijelaskan dengan benar, baik, dan lengkap; Pasien dapat didampingi oleh keluarganya atau tenaga advokasi medis; Tidak melakukan provokasi dan intimidasi dengan menggunakan dalil keilmuan; Risiko, rasa nyeri, dan ketidaknyaman (discomfort) dari tindakan dan pengobatan yang mungkin dialami pasien, harus dijelaskan secara terbuka; Persetujuan hanya diberikan oleh pasien, setelah pasien sungguh memahami semua fakta kesehatan dan penyakit yang dideritanya; Pasien menandatangani form persetujuan (pernyataan Persetujuan tindakan Kedokteran) hanya untuk satu jenis tindakan. Persetujuan Tindakan Kedokteran selalu diperbaharui terkait dengan perubahan apapun atas tindakan yang diberikan, semata-mata untuk kepentingan pasien; serta Pasien berhak untuk melihat data pengobatan dirinya. Terkait dengan perkembangan telemedicine, maka dibutuhkan penataan terhadap bentuk formal versi digital, dan sanksi yang berpangkal dari nilai harkat dan 
martabat manusia.Keberadaan Tenaga Advokasi medis, merupakan novelty dari Perjanjian terapeutik yang kiranya dapat dikonstruksi sebagai hukum positif, dalam rangka pembaharuan hukum kesehatan.

\section{REFERENCES}

Agus Budiyanto, et.al, Aspek Jasa Pelayanan Kesehatan Dalam Perspektif Perlindungan Pasien, Bandung: Karya Putra Darwati, 2010.

Bernard L Tanya, Pancasila Bingkai Hukum Indonesia, Yogyakarta,: Genta Publishing, 2014.

Cecep Triwibowo, Etika Hukum dan Kesehatan, Yogyakarta: Nuha Medika, 2014.

Drijarkara, Me-Negara, meng- Indonesia, Pancasila dari Sudut Pandang Filsafat Manusia, Yogyakarta: Penerbit USD, 2014.

Endang, Transaksi Terapeutik dalam Upaya Pelayanan Medis di Rumah Sakit, Bandung: PT CAB, 2009.

Guwandi, Inform Consent dan Inform Refusal, Jakarta: Balai Penerbit FKUI, 2003. Informed Consent, Jakarta: FHUI, 2004.

Hardijan Rusli ,Hukum Perjanjian Indonesia dan Common Law, Pustaka Sinar Harapan: Jakarta, 1996.

Harmien Hadiati Koeswadji, Hukum Kedokteran di Dunia Internasional, Makalah Simposium, Medical Law, Jakarta, 1993.

Kaelan, Filsafat Pancasila Pandangan Hidup Bangsa Indonesia, Yogyakarta: Paradigma, 2002.

Konsil Kedokteran Indonesia, Kemitraan dalam Hubungan Dokter-Pasien, Jakarta: KKI, 2006.

Khudzaifah Dimyati, Pemikiran Hukum, Konstruksi Epistemologis Berbasis Budaya Hukum Indonesia, 2014.

Mudji Sutrisno dalam LH Morgan, Sistem Pendidikan Nasional untuk Membangun Peradaban Bangsa, Yogyakarta: Gajah mada, 2011.

Petrus CKL Bello, Hukum dan Moralitas, Tinjauan Filsafat Hukum, Jakarta: Erlangga, 2012.

Pitono Soeparto, et.al, Etik dan Hukum di Bidang Kesehatan, Surabaya: Airlangga University

Samil Suprapti, Etika Kedokteran Indonesia, Jakarta: YPBS, 2001. 
Salim H.S, Hukum Kontrak: Teori \& Teknik Penyusunan Kontrak,, Sinar Grafika , Jakarta: 2004. 2006.

Perkembangan Hukum Kontrak di Luar KUH Perdata, Rajawali Press, Jakarta.

Sasrapratedja, Lima Gagasan yang tepat Mengubah Indonesia, Jakarta: Pusat Kajian Filsafat Pancasila, 2013.

Soekidjo Notoatmodjo, Etika Hukum Kesehatan, Jakarta: Rineka Cipta, 2010.

Sudjito, et.al, Jati Diri Manusia Indonesia Dalam Perspektif Pembentukan Karakter Bangsa, Yogyakarta: UGM, 2013.

, Memahami Manusia Indonesia secara Holistik, Yogyakarta: PSP Press, 2012.

Sumaryono, Etika Hukum, Relevansi Hukum Kodrat Thomas Aquinas, Yogyakarta: Kanisius, 2020.

Yeremias Jena, Wacana Tubuh dan Kedokteran, Sebuah Refleksi Filosofis, Jakarta: Atmajaya, 2014.

Yovita A. Mangesti, Hukum Berparadigma Kemanusiaan, Yogyakarta, Genta Publishing, 2016. 